\title{
Spatial and Temporal Variation of Rainwater Chemistry in Ile-Ife and Its Environ, Osun State, Nigeria
}

\author{
Aderonke. A. Okoya ${ }^{1}$, Bamikole. W. Osungbemiro ${ }^{1} \&$ Temi. E. Ologunorisa ${ }^{2}$ \\ ${ }^{1}$ Institute of Ecology and Environmental Studies, Obafemi Awolowo University, Ile - Ife, Osun State, Nigeria \\ ${ }^{2}$ Centre for Climate Change and Environmental Research, Osun State University, Osogbo, Nigeria \\ Correspondence: Aderonke. A. Okoya, Institute of Ecology and Environmental Studies, Obafemi Awolowo \\ University, Ile - Ife, Osun State, Nigeria. E-mail: ronkeokoya@yahoo.com
}

Received: March 30, 2016

doi:10.5539/jsd.v10n2p203
Accepted: June 8, $2016 \quad$ Online Published: March 30, 2017

URL: https://doi.org/10.5539/jsd.v10n2p203

\begin{abstract}
s
The study of the chemical composition of rain water was conducted in Ile - Ife and environs, an agrarian, commercial, residential and semi-industrialised center of Osun state Nigeria. This was with a view to assessing the impact of land use activities on rain water composition and the temporal variation of rainwater chemistry. Physico-chemical parameters such as Turbidity, pH, TDS, Conductivity, Oxygen parameters, Alkalinity, Acidity, Hardness and Major ions $\left(\mathrm{Ca}^{2+}, \mathrm{Mg}^{2+}, \mathrm{K}^{+}, \mathrm{Na}^{+}, \mathrm{NO}_{3}{ }^{-}, \mathrm{SO}_{4}^{-}, \mathrm{HCO}_{3}^{-}\right)$were determined, predominant ions were identified. Turbidity, pH, Conductivity, TDS, D.O B.O.D, Alkalinity, Acidity Hardness ranged between 2.90 $42.84 \mathrm{NTU}, 5.65-7.40,6.71-122.33 \mu \mathrm{Scm}^{-1}, 4.10-73.27 \mathrm{mg} / \mathrm{L}, 3.60-10.60 \mathrm{mg} / \mathrm{L}, 0.13-7.20 \mathrm{mg} / \mathrm{L}, 0.33-$ $22.0 \mathrm{mg} / \mathrm{L}, 2.00-15.00 \mathrm{mg} / \mathrm{L}, 0.04-1.23 \mathrm{CaCO}_{3} \mathrm{mg} / \mathrm{l}$ respectively. The dominant ions detected in the study were $\mathrm{HCO}_{3}{ }^{-}, \mathrm{Mg}^{2+}, \mathrm{Na}^{+}$and $\mathrm{Ca}^{2+}$. Generally, the mean concentration of ions as expressed in milli-equivalent per Litre showed order of dominance as $\mathrm{HCO}_{3}^{-}>\mathrm{NO}_{3}{ }^{-}>\mathrm{SO}_{4}{ }^{2-}$ for the anions and $\mathrm{Mg}^{2+}>\mathrm{Na}^{+}>\mathrm{Ca}^{2+}>\mathrm{K}^{+}$for cations. The study concluded that land use activities had influence on all the chemical composition of rain water in the study area but more on $\mathrm{pH}$, alkalinity, acidity, bicarbonate. Except sulphate and Nitrate, all other parameters recorded high values in dry season.
\end{abstract}

Keywords: rainwater, land use, Nigeria, physico-chemical composition, seasonal

\section{Introduction}

Rainwater has become an alternative source of water especially for domestic uses, agricultural uses and other potable uses where surface water resources are not available or sufficient (Muhammed and Mooyoung 2008; Yosef and Asmamaw 2015). Rainwater which is a mixed electrolyte contains varying amount of major and minor ions. Normal and unpolluted rain water is slightly acidic with the reference $\mathrm{pH}$ value for natural rainwater at 5.6 due to the carbonic acid (Galloway et al. 1982). However change in rainwater chemistry has become a great concern in Nigeria and the world at large because of occurrences of acid rain, heavy metal depositions, etc. which are associated with it. The assessment of the change in rainwater chemistry and the determination of factors influencing the recent atmospheric chemical alterations can be challenging. Chemical species and their concentration in rainwater are results of the various activities and conditions the atmosphere is subjected to. This is mostly as a result of man-made activities and land use activities (local source) in the area (Efe 2010; Oden 1976).

The chemistry of rainwater has been a subject to numerous investigations during the last two decades due to increase in environmental problems caused by chemicals in the rain, however the chemical composition of rainwater varies from site to site (Chughtai et al. 2014), from region to region due to influence of local sources. Other sources of variation in rain water chemistry include climate condition and level of exposure of the atmosphere (Efe 2005; Efe 2006). Rainwater chemistry is usually modified during its movement over the continent as it collects many air borne particles released by industries, urban settlements, terrestrial dust, agricultural activities and marine environment. (Prospero 1979).

Increasing development and industrialization worldwide has been the problem of acidic deposition, extra input of heavy metals and trace elements extending in recent times to other areas, such as East Asia, Africa (WHO 2011). Little effort has been made to determine the influence of other activities on the chemistry of rainwater. The 
objective of study is to determine the impact of land use activities on rain water composition. It is also aimed at determining the temporal variation of rainwater chemical composition in the study area.

\section{Methods}

\subsection{Description of the Study Area}

Ile-Ife and its environ covers two of the local governments (Ife Central and Ife East) in Osun State, southwestern Nigeria which lies at the intersection of the roads from Ibadan (64 km west), Ilesha, and Ondo (Fig. 1). It is about $200 \mathrm{~km}$ northeast of Lagos (the major industrial center of Nigeria), about $120 \mathrm{~km}$ north of the Atlantic Ocean. It has a population of about 400,000 (global.britannica.com/Ebchecked/topic/282720/Ile-Ife 2013 and Adamu 2000). The sampling stations were chosen based on land use activities in the study area using the land use classification model according to the National land use classification system and the Michigan Resource Information System (MIRIS) for land cover and land use mapping (Anderson et al. 1976). The land use activities considered include Industrial, Commercial, Residential and Agrarian (Fig. 2.) Three stations were selected for each land use and the descriptions are as follows:

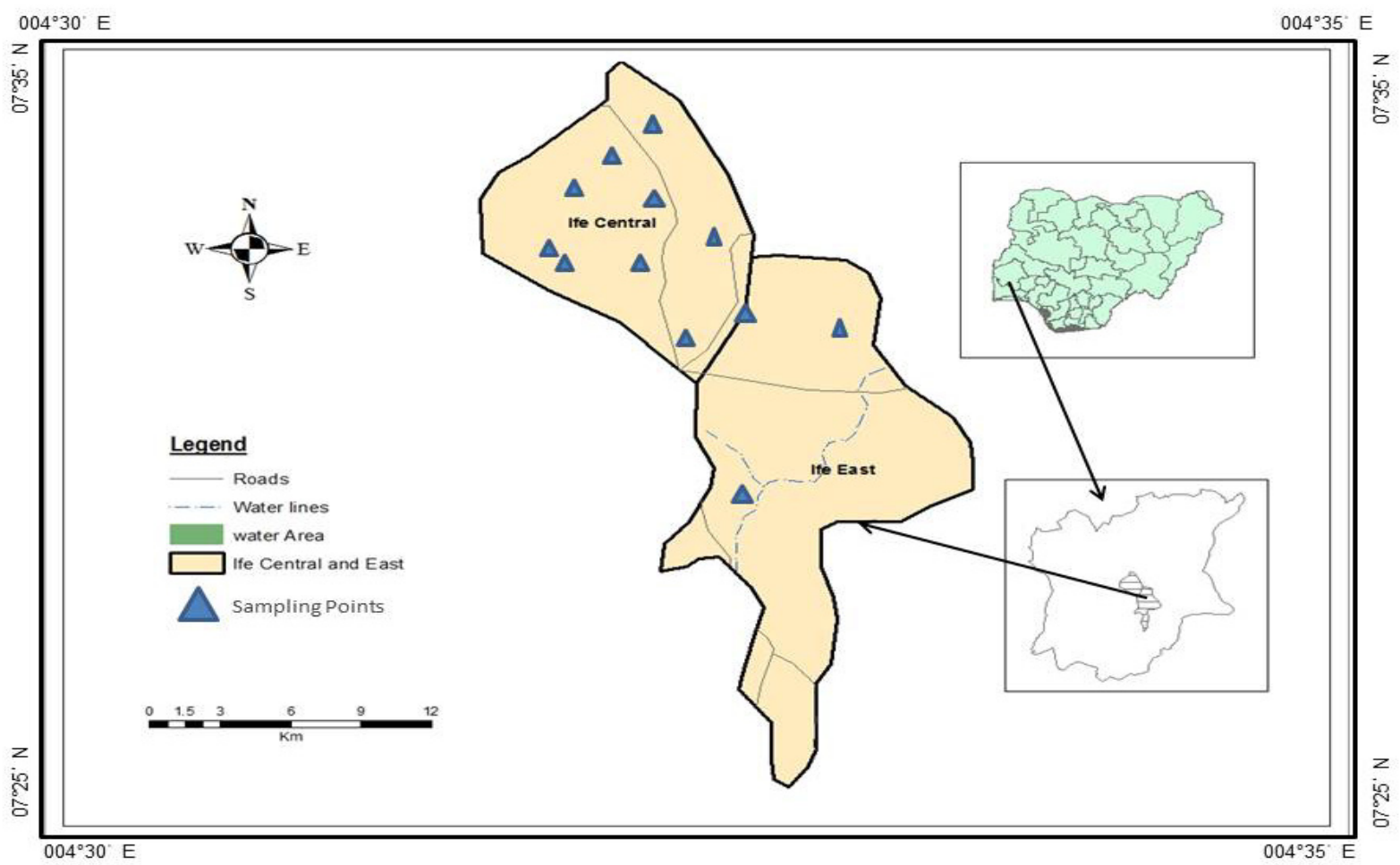

Figure 1. The Map of Osun State showing Ife Central and Ife East Local Government with the Sampling points 


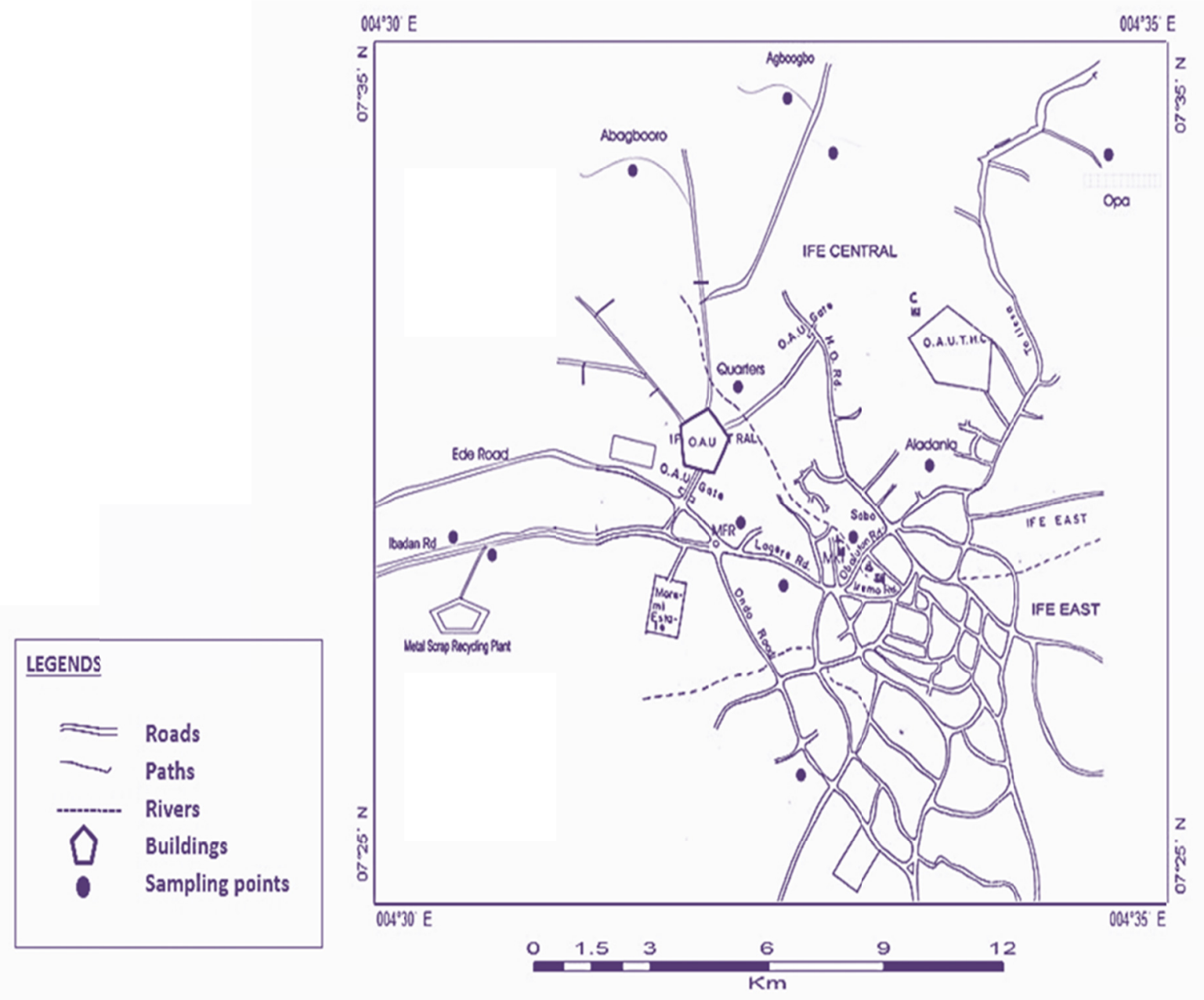

Figure 2. Map of Study Area Showing Sampling Points

\subsubsection{Agrarian Area}

The selected agrarian stations were Abagbooro, Abagbooro (Ayekoto) and Agbogbo. Abagbooro, Abagbooro (Ayekoto) are located at Latitude $07^{\circ} 32.39^{\prime} \mathrm{N}$ of the equator; Longitudes $004^{\circ} 30^{\prime} \mathrm{E}$ and Latitude $07^{\circ} 32^{\prime} \mathrm{N}$ of the equator; Longitudes $004^{\circ} 30^{\prime} \mathrm{E}$ of the prime meridian respectively. It is a typical rural area where farming is the main activity. Subsistence farming is the major farming system in the area with few cash crops such as Cocoa, Kolanut and Plantain. Bush burning (ancient farming practice) is still prominent in the area. Herbicides, insecticides, fungicides, and pesticides are commonly used in the area to enhance growth and productivity of the crops. There is no nearby highway therefore vehicular emission from traffic is negligible. Agbogbo which is the third agrarian station is also a rural area located about $2 \mathrm{~km}$ away from Obafemi Awolowo University Staff quarters on Latitude $07^{\circ} 32^{\prime} \mathrm{N}$ of the equator; Longitudes $004^{\circ} 33^{\prime} \mathrm{E}$ of the prime meridian. Bush burning is a common practice in the area. Cash crop farming is the major farming system with crops such as palm tree, cocoa as the major crops grown in the area. Herbicides, insecticides, fungicides, and pesticides are also used in the area to enhance growth and productivity of the crops. Palm oil and palm kernel business is the predominant business at the site.

\subsubsection{Commercial Area}

The selected commercial stations were Mayfair, Main market and Lagere. Mayfair is located on Latitude $07^{\circ} 29^{\prime}$ $\mathrm{N}$ of the equator and Longitudes $004^{\circ} 31^{\prime} \mathrm{E}$ of the prime meridian. The location is a moderately commercial center in Ile Ife with business shops, retail outlets, high vehicular movement and few residential buildings. The sampling site is located about $50 \mathrm{~m}$ from the nearest road with traffic density of 450 to 1500 vehicles per day (Ogunfowokan et al. 2004), which is further connected to a busy highway leading to Ibadan. Main market station is located at Latitude $07^{\circ} 29^{\prime} \mathrm{N}$ of the equator and Longitudes $004^{\circ} 33^{\prime} \mathrm{E}$ of the prime meridian. The location is a 
highly commercial center of Ile-Ife with full commercial activities all throughout the day. The area is also characterized with high traffic (1000 to 2000 vehicle per day) from vehicular activities due to the main road that passed by. There is little or no residential building. The sampling station is located at about 100 meters to the traffic congested road. Lagere axis station is located in the heart of Ile-Ife metropolis on Latitude $07^{\circ} 29^{\prime} \mathrm{N}$ of the equator and Longitudes $004^{\circ} 32^{\prime} \mathrm{E}$ of the prime meridian with high vehicular movement and moderate commercial activities. The sampling station is located about 50 meters from the nearest busy road (traffic density about 800 to 1500 vehicles per day).

\subsubsection{Residential Area}

The selected residential stations were Opa, Aladanla and OAU staff quarters (Road 7b cycle). Opa is located at Latitude $07^{\circ} 31^{\prime} \mathrm{N}$ of the equator and Longitudes $004^{\circ} 34^{\prime} \mathrm{E}$ of the prime meridian, it is the largest residential area in Ile-Ife. It is located in the southern part of Ile-Ife towards Ilesa. Opa is a pure residential area, with only few vehicular activities from resident of the area. The sampling point is about 500meters from the main road linking Ile-Ife with Ilesa which is under construction during the early period of this investigation. Aladanla, the second station is located on Latitude $07^{\circ} 30^{\prime} \mathrm{N}$ of the equator and Longitudes $004^{\circ} 34^{\prime} \mathrm{E}$ of the prime meridian. It is an old residential area in Ile-Ife with residential houses covering $80 \%$ of its entire land mass. The residents are average income earners; there are very low vehicular activities in this region. The sampling location is far away from the linking road that passes through Ile-Ife. Obafemi Awolowo University staff Quarter (Road 7b Cycle) is on Latitude $07^{\circ} 31^{\prime} \mathrm{N}$ and Longitude $004^{\circ} 32^{\prime} \mathrm{E}$ within the Obafemi Awolowo University Ile-Ife, it's an undisturbed residential area with evidence of habitation as far back as the inception of the university. It has lawn and large uncultivated natural vegetation. The only vehicular activities observed are from staff residing in the quarters. It has a road linking to the agrarian area (Abagbooro, Tonkere and Agbogbo).

\subsubsection{Industrial Area}

The selected industrial stations were Fasina A1, Fasina A2 and Ondo road. Fasina A1 and Fasina A2 are located along Ife-Ibadan express road within coordinate Latitude $07^{\circ} 29^{\prime} \mathrm{N}$ of the equator and Longitudes $004^{\circ} 31^{\prime} \mathrm{E}$ of the prime meridian and Latitude $07^{\circ} 29^{\prime} \mathrm{N}$ of the equator and Longitudes $004^{\circ} 28^{\prime} \mathrm{E}$ of the prime meridian respectively. The area host the major industry in Ile Ife and its environ, 'the Ife Scrap metal recycling plant' which is located in the northern part of Ile Ife and within Fasina community is about 100 metres away from the sampling station. The activities in the industry involve packing of metal scraps, cutting, melting of metal scraps, and recycling of metals to other forms (Salami et al. 2014). It has a heavy duty plant with heavy exhaust from machines and equipment. Vehicular activities are also high in this location due to a major busy road linking Ife and Ibadan which passes through the community with a busy high way traffic (traffic density 1000 to 5000 vehicles per day). Ondo road which is the third station is on the southern part of Ile Ife along Ondo township road, at Latitude $07^{\circ} 26^{\prime} \mathrm{N}$ of the equator and Longitudes $004^{\circ} 33^{\prime} \mathrm{E}$ of the prime meridian. The area is a semi industrialized area because it is predominantly occupied by saw-mail activities. The saw mail industries have been on for more than four decades, leading to high rate of exhaust from Timber Lorries activities and milling engines. The sampling site is located about 10 meters from the road with traffic density of about $2000-3000$ vehicles per day.

\subsection{Climate and Meteorology of the Area}

The study area like most parts of Nigeria is characterized by two distinct climatic seasons, the dry season from November to March, and the wet season from April to October. The overall mean annual temperature and mean annual rainfall of Ile-Ife are $27^{\circ} \mathrm{C}$ and $1000-1250 \mathrm{~mm}$ respectively (Badejo et. al., 2011). The mean annual temperatures of 2011,2012 and 2013 in the study area are $25.7^{\circ} \mathrm{C} \pm 2.82,25.5^{\circ} \mathrm{C} \pm 2.75$ and $25.45^{\circ} \mathrm{C} \pm 2.61$ respectively (Fig 3a). The mean annual rainfall of 2011, 2012 and 2013 are $1302 \mathrm{~mm} \pm 0.053,1361 \mathrm{~mm} \pm 0.050$ and $1452 \mathrm{~mm} \pm 0.049$ respectively (fig. $3 \mathrm{~b}$ ). The wet season in the study area extends to seven months, with its beginning and ending (transition phase) marked by torrential rains and thunderstorms. Wet season in the study area has two peaks; July $(173.49 \mathrm{~mm})$ and September $(272.55 \mathrm{~mm})$ with a dry spell in August (August break) (Fig. 3c). During the period of study (October 2012 to September 2013) rainfall was highest in September 2013 and in October 2012, there was a dry spell in December 2012 and January 2013 (Fig. 3d). Monthly temperature during the study period has a peak in January/February and the lowest in July/August. (Fig. 3e). Relative humi dity was highest in July to September and lowest in December/February. (Fig. 3f) 


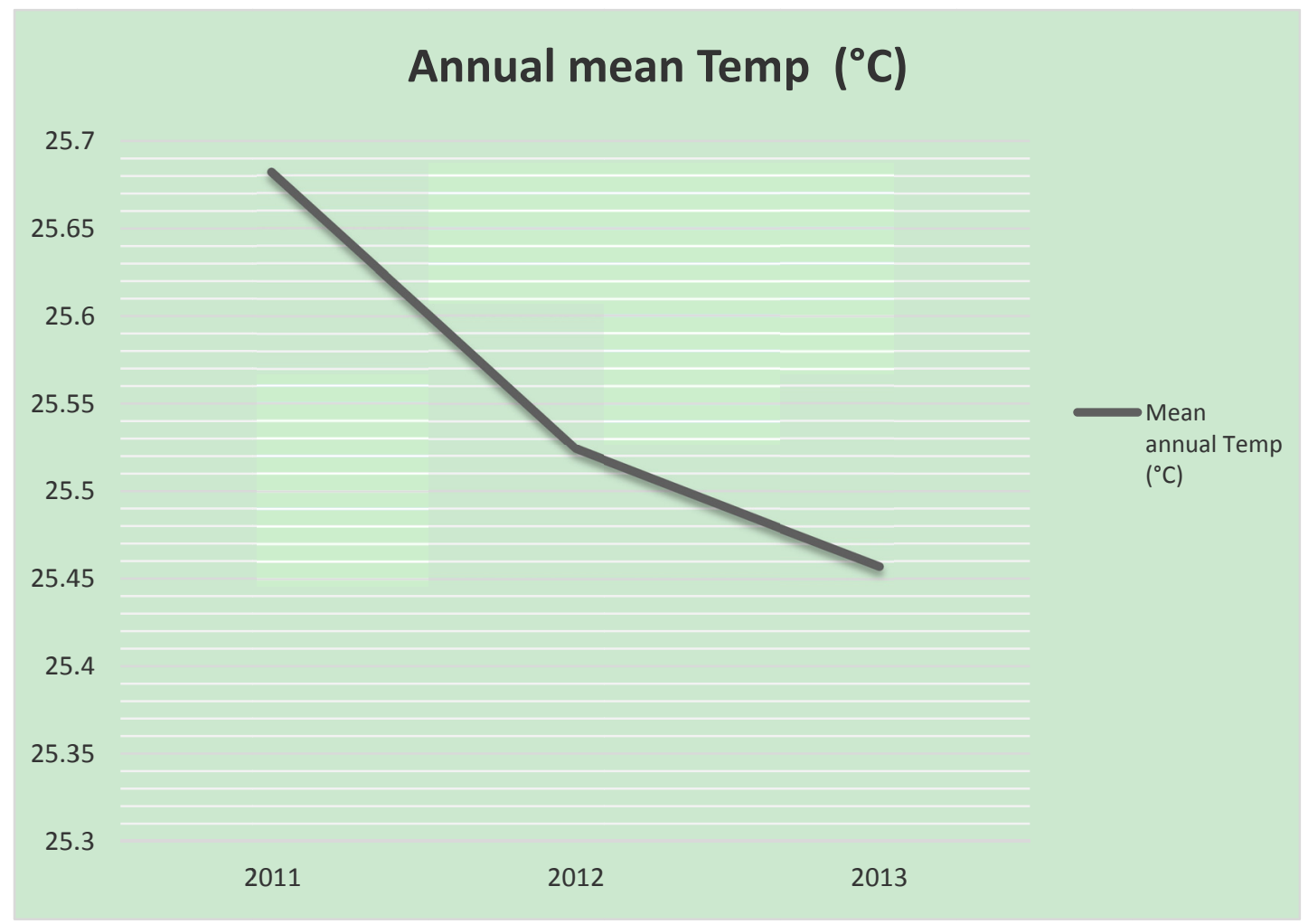

Figure 3a. Annual mean Temperature (2011 - 2013)

Source: Department of Physics Obafemi Awolowo University Meteorological observation station, Ile-Ife

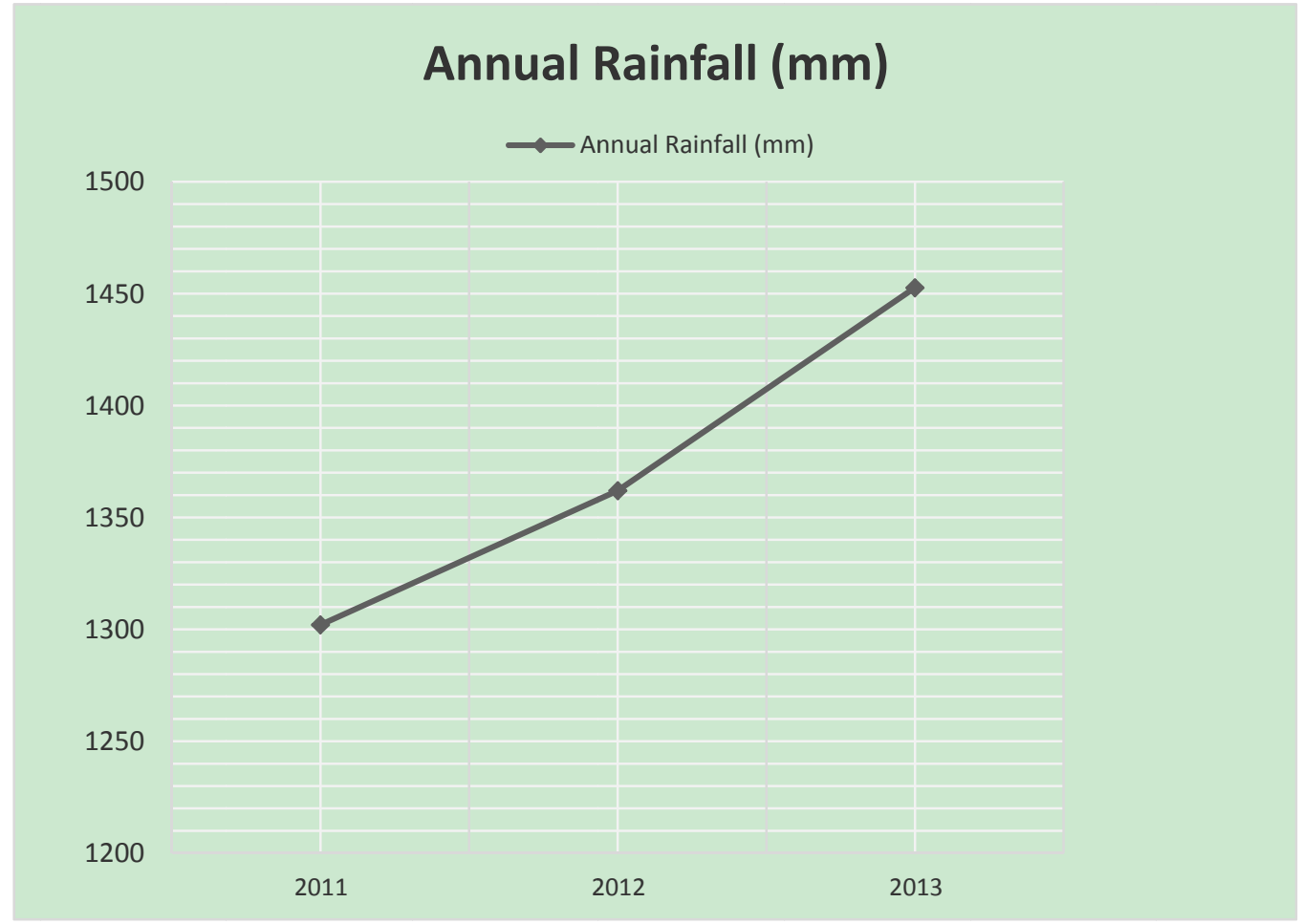

Figure 3b. Annual sum of Rainfall 2011 - 2013

Source: Department of Physics Obafemi Awolowo University Meteorological observation station, Ile-Ife 


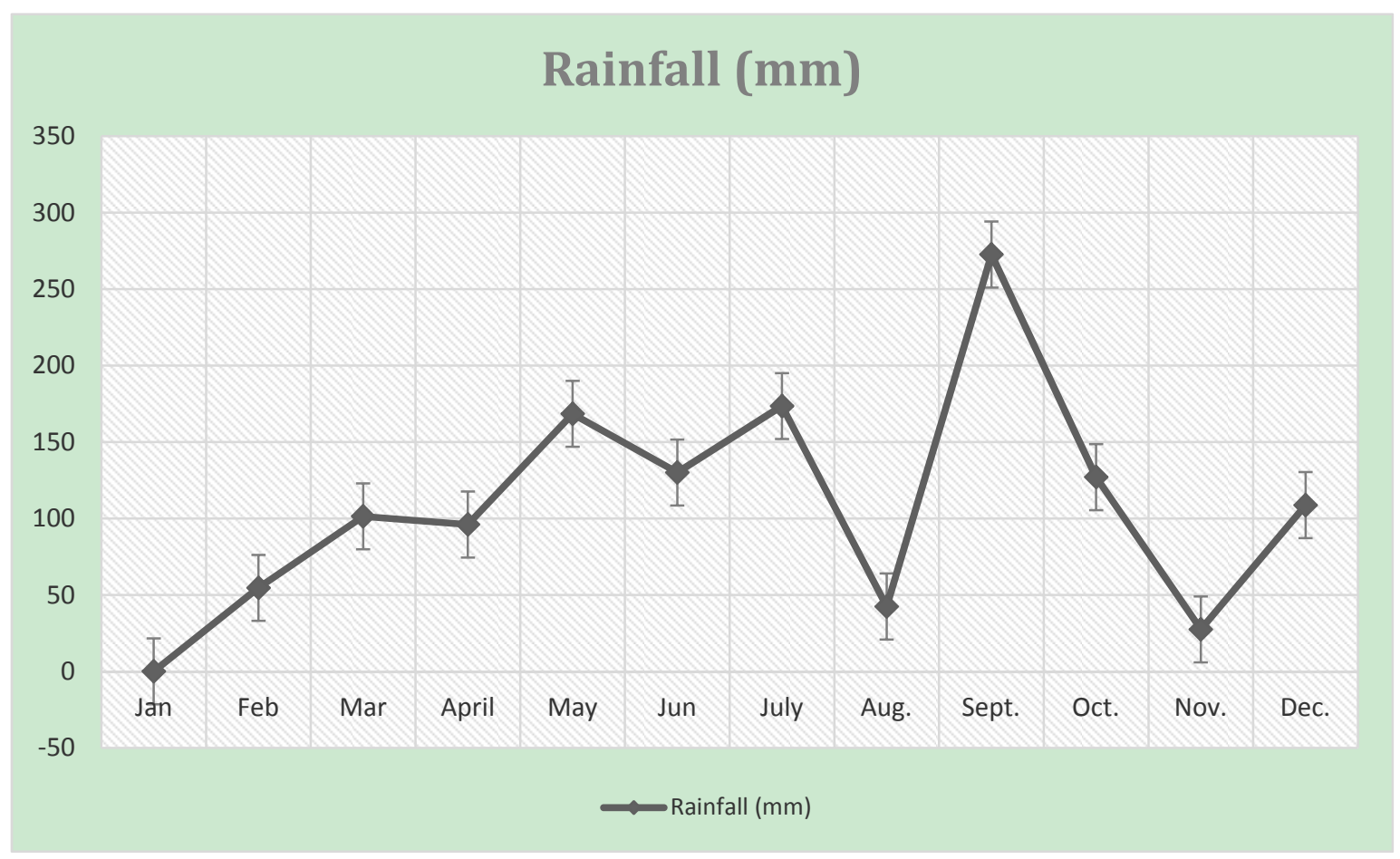

Figure 3c. The Monthly Mean Rainfall at Ile-Ife, Osun State (2011 to 2013)

Source: Department of Physics Obafemi Awolowo University Meteorological observation station, Ile-Ife

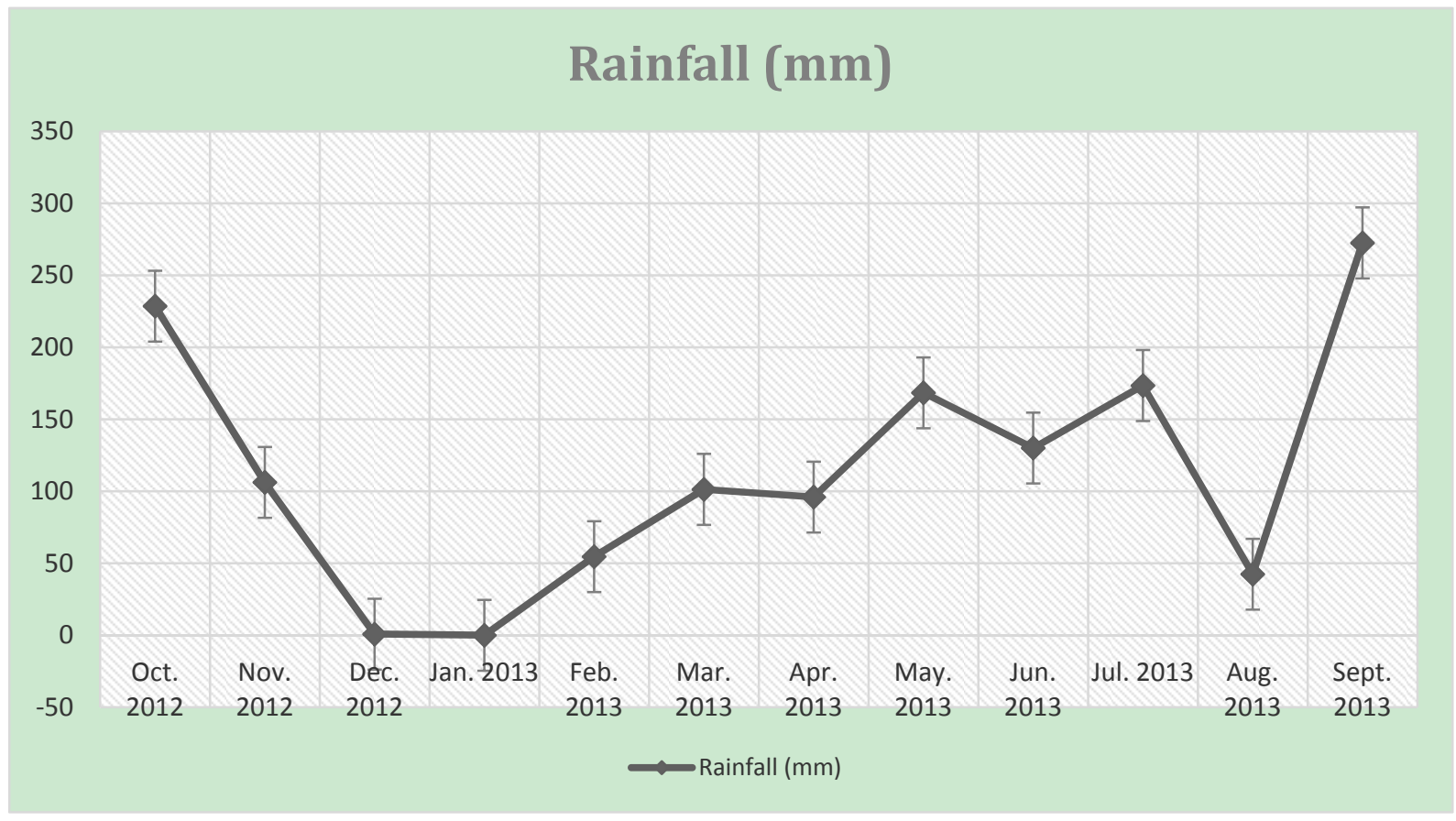

Figure 3d. The monthly mean Rainfall at Ile-Ife, Osun State during the Duration of Sampling Source: Department of Physics Obafemi Awolowo University Meteorological observation station, Ile-Ife 


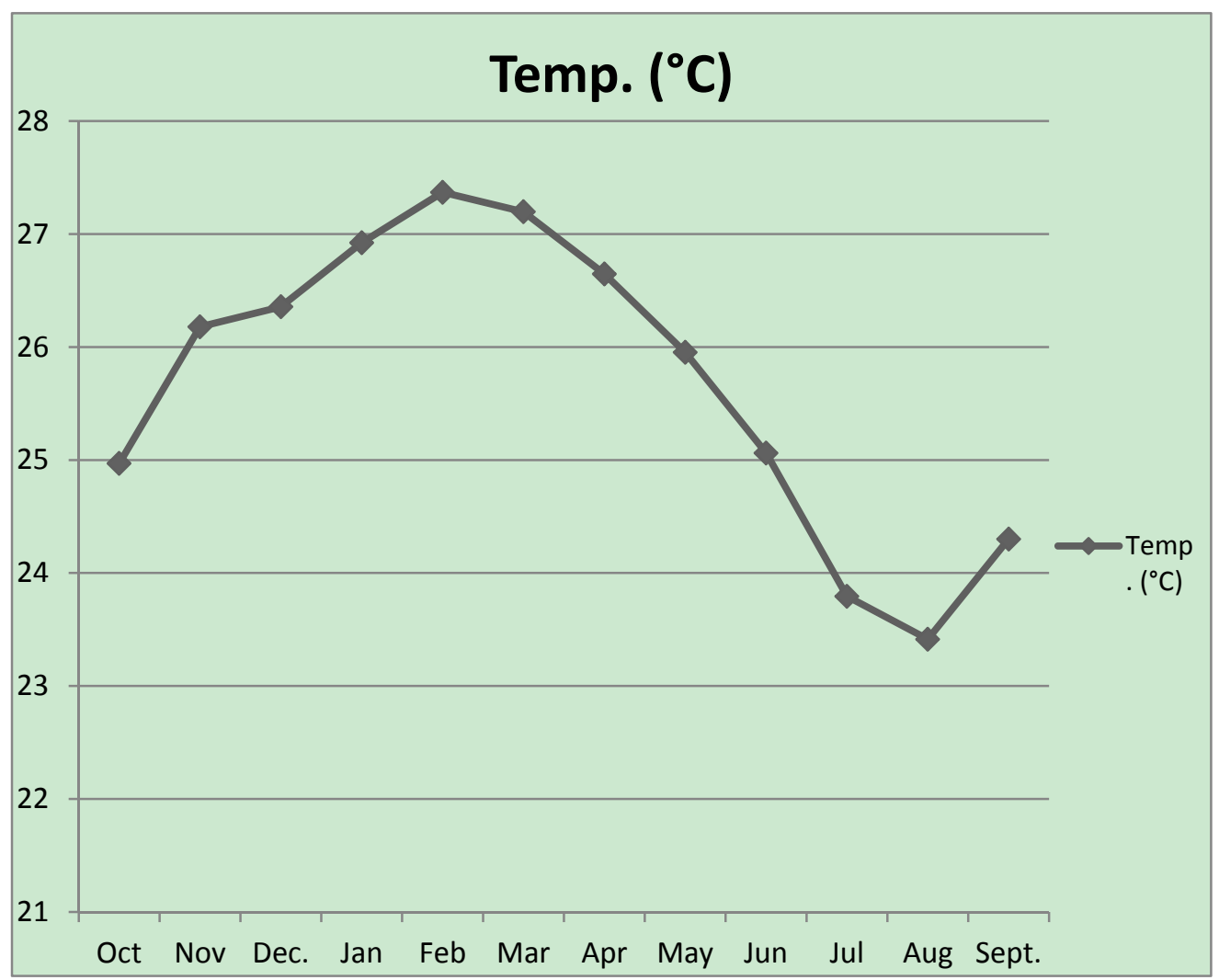

Figure 3e. The monthly mean Temperature at Ile-Ife, Osun State

Source: Department of Physics Obafemi Awolowo University Meteorological observation station, Ile-Ife

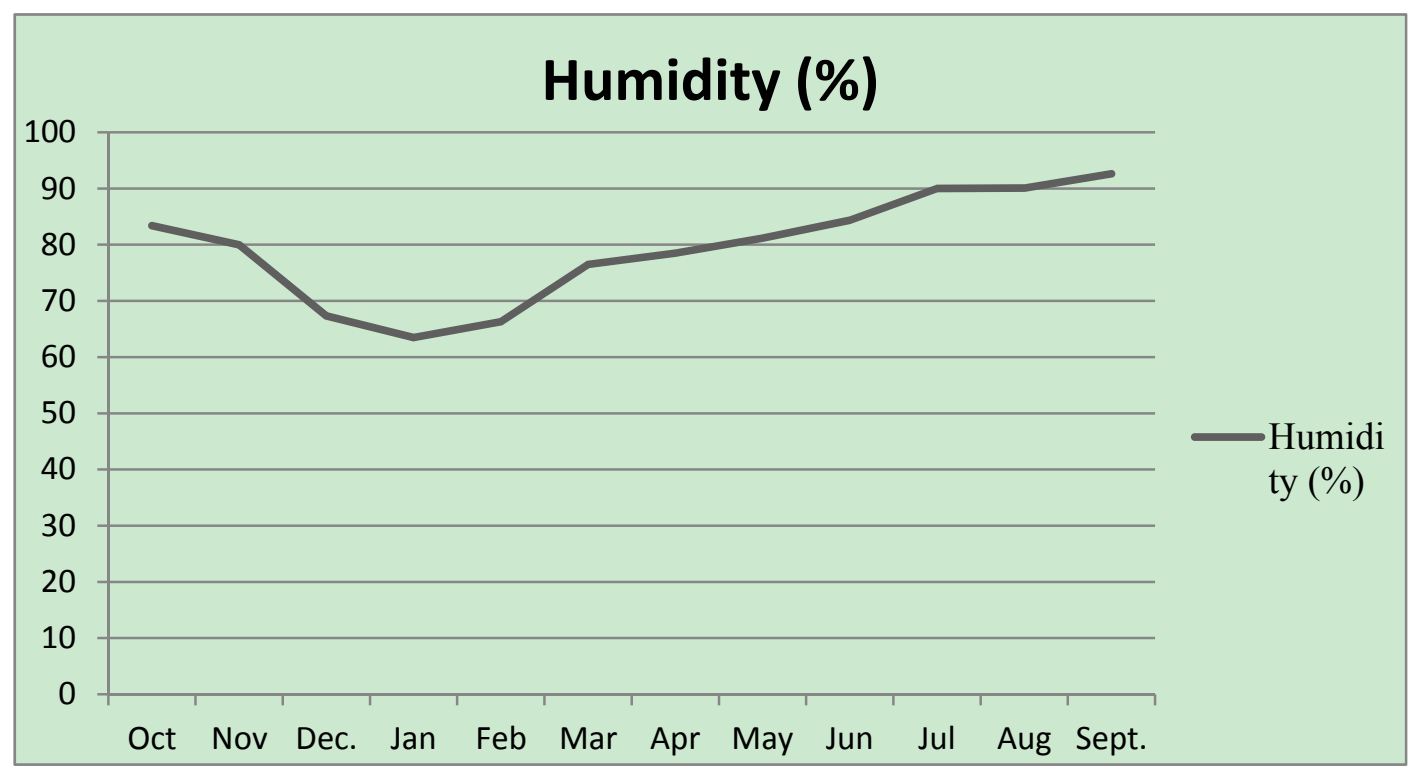

Figure 3f. The monthly mean Humidity at Ile-Ife, Osun State

Source: Department of Physics Obafemi Awolowo University Meteorological observation station, Ile-Ife

\section{Sample collection, preparation and Analyses}

\section{Sample collection}

A high density polyethylene container sampler of known weight and volume (anchor International; model 
TE-78-100) was soaked in $0.1 \mathrm{M} \mathrm{HNO}_{3}$ for three days and thoroughly rinsed with distilled water before being labeled for easy identification. The containers were mounted just before rainfall commences at 2 meters above ground level at every sampling station to avoid surface contamination and free fall collection was taken. Rainwater collection (using the HDPE container) commenced in October, 2012 and ended in September, 2013. The air temperature after each rain event was taken and recorded.

\subsection{Sample Preparation and Analyses}

Samples for Dissolved Oxygen (DO) and Biochemical Oxygen Demand (BOD5) were collected immediately using oxygen bottles. Dissolved Oxygen samples were fixed on the field with $2 \mathrm{ml}$ of Winkler I reagent $\left(\mathrm{MnSO}_{4}\right)$ and $2 \mathrm{ml}$ of Winkler II reagent $(\mathrm{KI} / \mathrm{NaOH})$ solutions. Biochemical Oxygen demand samples were kept in the dark cupboard at room temperature upon reaching the laboratory for five days. At the laboratory $\mathrm{pH}$ of the samples was determined using a Lovibond (1000-model) $\mathrm{pH}$ comparator and a well calibrated Eniscope $\mathrm{pH}$ meter (pHs3B Model) for confirmation. Physical parameters such as turbidity, volume of rain water were determined using gravimetric method. The chemical parameters determined in rain water samples were: $\mathrm{pH}$, total dissolved solids, conductivity, sulphate, nitrate, alkalinity, acidity, oxygen parameters and $\mathrm{HCO}_{3}{ }^{-}$using standard methods. The rain water samples were digested using $2.5 \mathrm{ml}$ of conc. $\mathrm{HNO}_{3}$ and $2.5 \mathrm{ml}$ of conc. $\mathrm{HClO}_{4}$ mixture. The concentration of $\mathrm{Ca}^{2+}, \mathrm{Mg}^{2+}, \mathrm{K}^{+}, \mathrm{Na}^{+}$were obtained using atomic absorption spectrophotometer.

\subsection{Statistical Analyses of Data}

The data obtained were subjected to descriptive, analysis of variance, correlation statistics and Duncan's multiple range test. The source apportionment analysis was done on Statistical Package for Social Sciences (Version 17.0). The values of all parameters were log-transformed to ensure normal distribution. Principal Component Analysis was therefore carried out data.

\section{Result and Discussion}

A total of 120 rainwater samples were collected from twelve locations. The land use areas investigated include industrial, residential, commercial, and agrarian. The $\mathrm{pH}$ values of rainwater in this studied area ranged between 5.65 and 7.40 with a mean of $6.46 \pm 0.07$. The $\mathrm{pH}$ of normal rainwater has a threshold of 5.6 (3). The high $\mathrm{pH}$ value recorded in the study can be attributed to the presence of $\mathrm{pH}$ neutralizing cations present in the rain water samples of the study area. This is in line with the report of Ranjit et al. (1998) and Remirez et al. (2010). pH was higher at agrarian area $(6.87 \pm 0.12)$ and significantly $(\mathrm{P}<0.5)$ different from other land use areas except residential area (Table 1), this could be due to the presence of high concentration of acid neutralizing ions $\left(\mathrm{Mg}^{2+}\right.$, $\mathrm{Ca}^{2+}, \mathrm{Na}^{+}$and $\left.\mathrm{HCO}_{3}^{-}\right)$in the area as supported by Ranjit et al. (1998), Sillapapiromsuk and Chantara (2010). pH was also lower at commercial area $(6.13 \pm 0.11)$ as a result of high concentration of Sulphate ion from fuel combustion (Shivashankara and Nagendra 2012; Igwo-Ezikpe and Awodele 2010) compared to other locations throughout the study period (Fig. 4). The neutralization of rainwater by acid neutralizing cations varies significantly with their concentration at the different land use areas thereby resulting to the variation in $\mathrm{pH}$ value recorded.

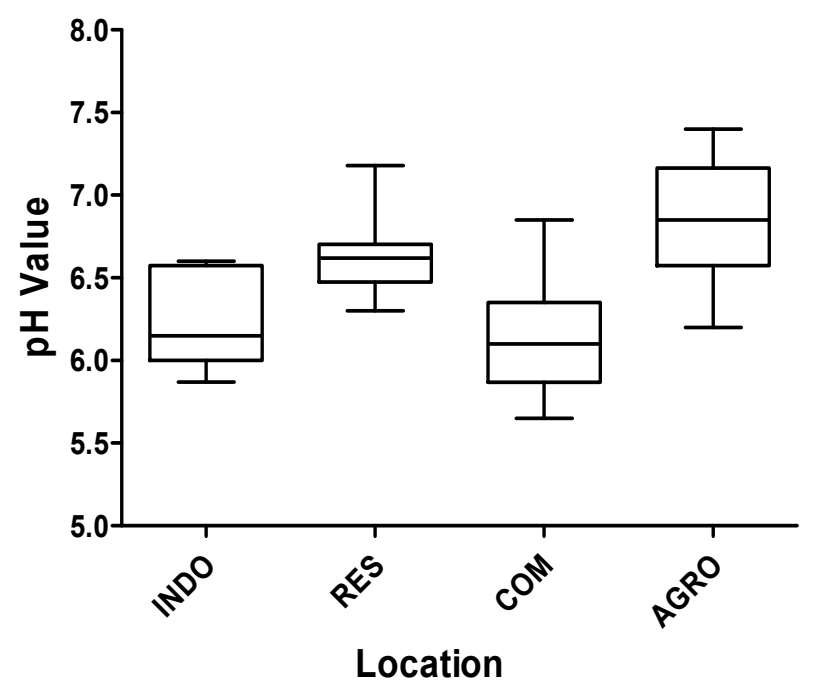

Figure 4. $\mathrm{pH}$ variation among land use areas 
Industrial area with the highest sulphate value $(0.17 \mathrm{mg} / \mathrm{L})$, the lowest acid neutralizing cation concentrations $\left(\mathrm{Ca}^{2+}\left(0.10 \mathrm{mg} / \mathrm{L}, \mathrm{Na}^{+}(0.12 \mathrm{mg} / \mathrm{l})\right.\right.$ and $\left.\mathrm{Mg}^{2+}(0.09 \mathrm{mg} / \mathrm{L})\right)$ (Table 2) recorded the lowest Alkalinity (3.75 $\left.\mathrm{mgCaCO}_{3} / \mathrm{L}\right)$ and highest acidity $\left(7.63 \mathrm{mgCaCO}_{3} / \mathrm{L}\right)$ concentration (Table 1). Agrarian area recorded the highest Alkalinity $\left(13.97 \mathrm{mgCaCO}_{3} / \mathrm{L}\right)$ and lowest concentration of acidity $\left(3.79 \mathrm{mgCaCO}_{3} / \mathrm{L}\right)($ Table 1$)$ in the study area, this may be due to the dominance of acid neutralizing cations $\left(\mathrm{Ca}^{2+}\left(0.15 \mathrm{mg} / \mathrm{L}, \mathrm{Na}^{+}(0.20 \mathrm{mg} / \mathrm{l}) \mathrm{and} \mathrm{\textrm {Mg } ^ { 2 + }}\right.\right.$ $(0.09 \mathrm{mg} / \mathrm{L}))$ in the area compare to other land use areas of Ile-Ife (Table 2) as supported by Shivashankara and Nagendra (2012). Land Use has a high influence on the acidity and total alkalinity concentration of rain water in the study area. Land use activities have a significant influence on the acidity and alkalinity concentration of rain water, alkalinity and acidity are significantly $(\mathrm{P}<0.05)$ different among the land use areas (Table 1$)$. TDS was higher $(23.76 \mathrm{mg} / \mathrm{L})$ at agrarian area because of the increased occurrence of soil dust from farming activities and biomass burning than residential $(21.86 \mathrm{mg} / \mathrm{L})$, Industrial $(17.64 \mathrm{mg} / \mathrm{L})$ and commercial $(10.50 \mathrm{mg} / \mathrm{L})$ (Table 1). According to Kondal et al. (2011), TDS in rainwater increases if the dust suspended particles increases. High concentration of cations at agrarian and residential area influenced the higher conductivity value (37.81 and $17.47 \mu \mathrm{Scm}^{-1}$ ) observed at both land use areas respectively (Table 1) since conductivity is a measure of ionic concentration of the water. The highest $\mathrm{HCO}_{3}{ }^{-}$concentration was recorded at Agrarian Area $(16.76 \mathrm{mg} / \mathrm{L})$ and the lowest concentration recorded at commercial Area $(4.92 \mathrm{mg} / \mathrm{L})$ (Table II). This is in line with the trend observed in the alkalinity values at agrarian and commercial land use areas (http://www.vccs.edu/exam_prep/alkalinity.html). The highest $\mathrm{SO}_{4}{ }^{2-}$ values $(0.17 \pm 0.01 \mathrm{mg} / \mathrm{L})$ for land use areas were recorded at both Industrial and commercial areas (Table 2), this can be attributed to fuel combustion from vehicular and mechanical activities as supported by Dorothy (1962), Efe (2011), Jitendra (2012) and Shivashankara and Nagendra (2012). The highest and the lowest observed mean value for nitrate concentration was recorded at Agrarian Area $(1.00 \pm 0.15 \mathrm{mg} / \mathrm{L})$ and commercial Area $(0.73 \pm 0.11 \mathrm{mg} / \mathrm{L})$ respectively (Table 2). This may be as a result of the use of fertilizers at agrarian area than in other land use areas as supported by Jitendra (2012). The major cations are more dominant at Agrarian area than in other areas in the study area, probably due to alkali soil re-suspension (Sillapapiromsuk and Chantara 2010).

Table 1. Variation in major chemical parameter of Rain Water at Different Land Use Locations of the Study Area, Ile-Ife, Osun State

\begin{tabular}{|c|c|c|c|c|c|c|}
\hline PARAMETER & $\begin{array}{l}\text { Industrial } \\
\text { Mean } \pm \text { S.E }\end{array}$ & $\begin{array}{l}\text { Residential } \\
\text { Mean } \pm \text { S.E }\end{array}$ & $\begin{array}{l}\text { Commercial } \\
\text { Mean } \pm \text { S.E }\end{array}$ & $\begin{array}{l}\text { Agrarian } \\
\text { Mean } \pm \text { S.E }\end{array}$ & $\mathrm{F}$ & $\mathrm{P}$ \\
\hline $\mathrm{pH}$ & $6.23^{\mathrm{a}} \pm 0.09$ & $6.62^{\mathrm{b}} \pm 0.075$ & $6.13^{\mathrm{a}} \pm 0.11$ & $6.87^{b} \pm 0.12$ & 11.791 & 0.000 \\
\hline Cond. $\left(\mu \mathrm{Scm}^{-1}\right)$ & $29.43^{a} \pm 10.72$ & $36.45^{b} \pm 4.63$ & $17.47^{\mathrm{a}} \pm 4.46$ & $37.81^{\mathrm{a}} \pm 6.53$ & 1.739 & 0.176 \\
\hline TDS (mg/L) & $17.64^{\mathrm{ab}} \pm 6.42$ & $21.86^{\mathrm{ab}} \pm 2.79$ & $10.50^{\mathrm{a}} \pm 2.68$ & $23.76^{b} \pm 3.86$ & 1.943 & 0.140 \\
\hline $\mathrm{DO}(\mathrm{mg} / \mathrm{L})$ & $6.19^{a} \pm 0.35$ & $6.87^{\mathrm{a}} \pm 0.55$ & $6.41^{\mathrm{a}} \pm 0.39$ & $6.33^{a} \pm 0.46$ & 0.437 & 0.728 \\
\hline $\mathrm{BOD}_{5}(\mathrm{mg} / \mathrm{L})$ & $1.36^{\mathrm{a}} \pm 0.32$ & $2.29^{\mathrm{a}} \pm 0.82$ & $1.67^{\mathrm{a}} \pm 0.53$ & $1.57^{\mathrm{a}} \pm 0.378$ & 0.535 & 0.661 \\
\hline $\begin{array}{l}\text { T. Alkalinity } \\
\left(\mathrm{mgCaCO}_{3} / \mathrm{L}\right)\end{array}$ & $3.75^{\mathrm{a}} \pm 0.77$ & $7.23^{\mathrm{a}} \pm 0.78$ & $4.10^{\mathrm{a}} \pm 0.79$ & $13.97^{b} \pm 2.09$ & 14.444 & 0.000 \\
\hline $\begin{array}{l}\text { Acidity } \\
\left(\mathrm{mgCaCO}_{3} / \mathrm{L}\right)\end{array}$ & $7.63^{b} \pm 1.30$ & $4.83^{a} \pm 0.52$ & $5.07^{\mathrm{a}} \pm 0.63$ & $3.79^{\mathrm{a}} \pm 0.62$ & 3.918 & 0.016 \\
\hline
\end{tabular}


Table 2. Variation in Major Ions Composition of Rain Water at Different Land Use Locations of the Study Area, Ile-Ife, Osun State

\begin{tabular}{lllllll}
\hline \multirow{2}{*}{ PARAMETER } & $\begin{array}{l}\text { Industrial } \\
\text { Mean } \pm \text { S.E }\end{array}$ & $\begin{array}{l}\text { Residential } \\
\text { Mean } \pm \text { S.E }\end{array}$ & $\begin{array}{l}\text { Commercial } \\
\text { Mean } \pm \text { S.E }\end{array}$ & $\begin{array}{l}\text { Agrarian } \\
\text { Mean } \pm \text { S.E }\end{array}$ & F & P \\
\hline $\mathrm{HCO}_{3}{ }^{-}(\mathrm{mg} / \mathrm{l})$ & $4.50^{\mathrm{a}} \pm 0.92$ & $8.68^{\mathrm{a}} \pm 0.94$ & $4.92^{\mathrm{a}} \pm 0.95$ & $16.76^{\mathrm{b}} \pm 2.51$ & 14.439 & 0.000 \\
$\mathrm{NO}_{3}{ }^{-}(\mathrm{mg} / \mathrm{l})$ & $0.73^{\mathrm{a}} \pm 0.11$ & $0.84^{\mathrm{a}} \pm 0.13$ & $0.83^{\mathrm{a}} \pm 0.14$ & $1.00^{\mathrm{a}} \pm 0.15$ & 0.730 & 0.541 \\
$\mathrm{SO}_{4}{ }^{2-}(\mathrm{mg} / \mathrm{l})$ & $0.17^{\mathrm{a}} \pm 0.012$ & $0.15^{\mathrm{a}} \pm 0.01$ & $0.17^{\mathrm{a}} \pm 0.01$ & $0.15^{\mathrm{a}} \pm 0.02$ & 0.570 & 0.639 \\
$\mathrm{Ca}^{2+}(\mathrm{mg} / \mathrm{l})$ & $0.10^{\mathrm{a}} \pm 0.01$ & $0.14^{\mathrm{a}} \pm 0.03$ & $0.09^{\mathrm{a}} \pm 0.01$ & $0.15^{\mathrm{a}} \pm 0.03$ & 1.74 & 0.18 \\
$\mathrm{~K}^{+}(\mathrm{mg} / \mathrm{l})$ & $0.12^{\mathrm{a}} \pm 0.01$ & $0.16^{\mathrm{a}} \pm 0.05$ & $0.09^{\mathrm{a}} \pm 0.01$ & $0.17^{\mathrm{a}} \pm 0.05$ & 0.96 & 0.42 \\
$\mathrm{Mg}^{2+}(\mathrm{mg} / \mathrm{l})$ & $0.09^{\mathrm{a}} \pm 0.01$ & $0.10^{\mathrm{a}} \pm 0.01$ & $0.07^{\mathrm{a}} \pm 0.01$ & $0.09^{\mathrm{a}} \pm 0.01$ & 0.80 & 0.50 \\
$\mathrm{Na}^{+}(\mathrm{mg} / \mathrm{l})$ & $0.12^{\mathrm{a}} \pm 0.02$ & $0.21^{\mathrm{a}} \pm 0.09$ & $0.12^{\mathrm{a}} \pm 0.02$ & $0.20^{\mathrm{a}} \pm 0.06$ & 0.79 & 0.51 \\
\hline
\end{tabular}

Note: Values followed by the same alphabet in the same row are not significantly different at $P<0.05$ level according to new Duncan Multiple Range Test.

Figure 4 and Table 3 show temporal variation of chemical composition of rain water in the study area. Turbidity, $\mathrm{pH}$, Conductivity, TDS, DO and BOD were highest in February than other months. This may be because the first rainfall of the year occurred in February and the dust pollutants and particulate matter in the atmosphere were quite high and were dissolved to the rain water. This tends to increase the cloudiness of rainwater and increase conductivity and TDS during this period as suggested by Kondal et al. (2011). In contrast, Fig. 5 shows a sharp decrease in the concentration of all the above parameter from April to August, this may be due to frequent precipitation (rain) during the wet season that regularly flushes down particulates and dust from the atmosphere, thereby minimizing accumulation of dust particulate in rainwater during wet season as supported by Narayana (1991). This also explains why DO and $\mathrm{BOD}_{5}$ were higher in February than other months. pH was also highest (6.74) in February (scanty rain), and lowest (6.25) in August (Frequent rain) this could be due to high and low load of acid neutralizing particulates in the atmosphere that is washed down by the rain in the months respectively (Table 3). This result also agrees with Atobatele (2008) that $\mathrm{pH}$ decreases with increase in rainfall. 

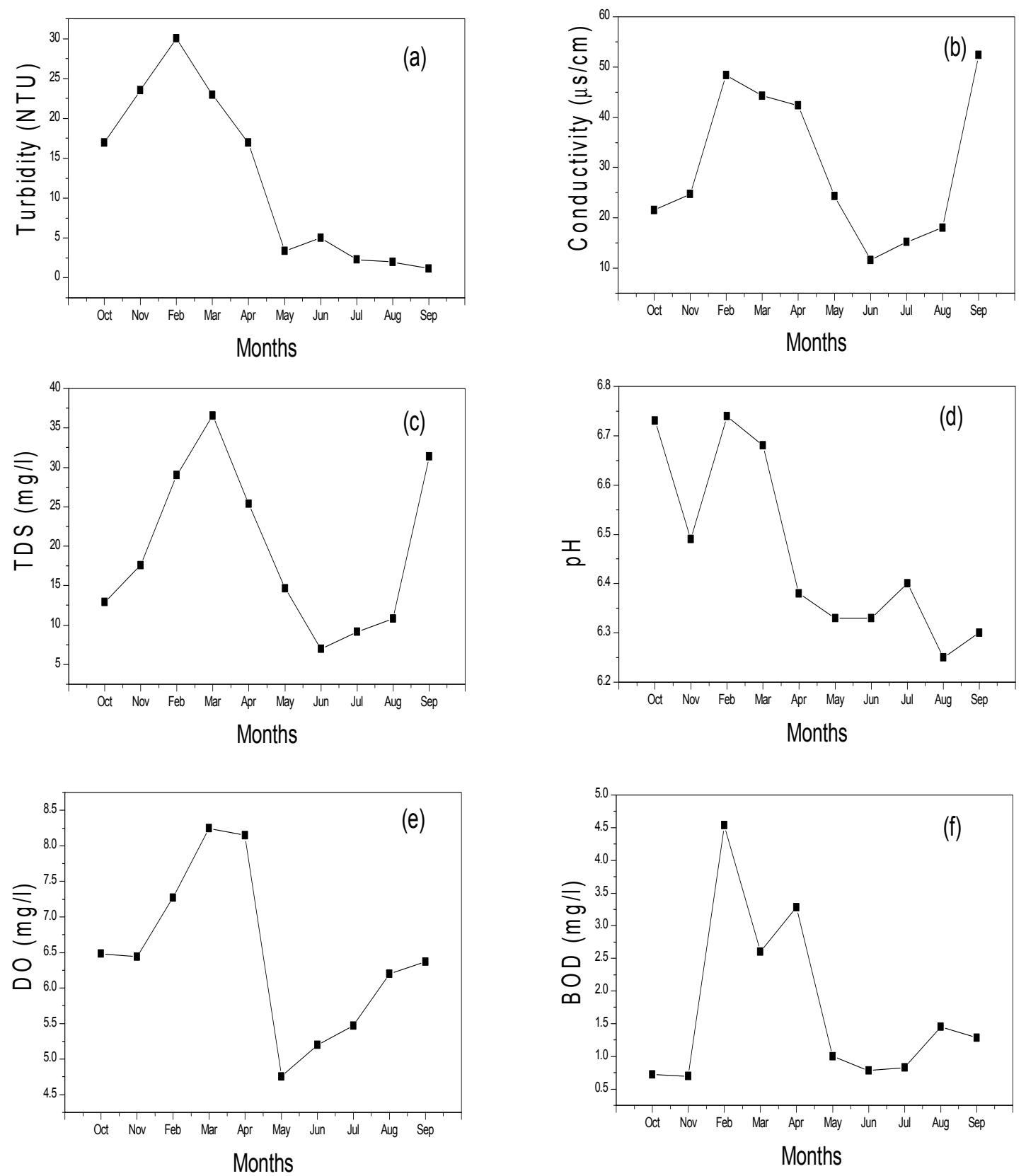

Figure 5. Monthly (Oct 2012 -Sept 2013) Variation of Specific Rainwater Parameters 
Table 3. Monthly (Oct 2012 -Sept 2013) Variation in the Major Ions of Rain Water in Ile-Ife

\begin{tabular}{|c|c|c|c|c|c|c|c|c|c|c|}
\hline & $\begin{array}{l}\text { OCT. } \\
\text { Mean } \\
\pm \text { S.E }\end{array}$ & $\begin{array}{l}\text { NOV. } \\
\text { Mean } \\
\pm \text { S.E }\end{array}$ & $\begin{array}{l}\text { FEB. } \\
\text { Mean } \\
\pm \text { S.E }\end{array}$ & $\begin{array}{l}\text { MAR } \\
\text { Mean } \\
\pm \text { S.E }\end{array}$ & $\begin{array}{l}\text { APRI } \\
\text { Mean } \\
\pm \text { S.E }\end{array}$ & $\begin{array}{l}\text { MAY } \\
\text { Mean } \\
\pm \text { S.E }\end{array}$ & $\begin{array}{l}\text { JUNE } \\
\text { Mean } \\
\pm \text { S.E }\end{array}$ & $\begin{array}{l}\text { JULY } \\
\text { Mean } \\
\pm \text { S.E }\end{array}$ & $\begin{array}{l}\text { AUG. } \\
\text { Mean } \\
\pm \text { S.E. }\end{array}$ & $\begin{array}{l}\text { SEPT. } \\
\text { Mean } \\
\pm \text { S.E }\end{array}$ \\
\hline $\begin{array}{l}\text { Alkalinity } \\
\left(\mathrm{mgCaCO}_{3} / \mathrm{L}\right)\end{array}$ & $\begin{array}{l}9.92 \quad \mathrm{a} \\
\pm 4.14\end{array}$ & $\begin{array}{l}9.92 \\
\pm 4.48\end{array}$ & $\begin{array}{l}7.84 \quad \mathrm{a} \\
\pm 3.86\end{array}$ & $\begin{array}{l}9.83 \quad \mathrm{a} \\
\pm 2.99\end{array}$ & $\begin{array}{l}7.67 \quad \mathrm{a} \\
\pm 3.69\end{array}$ & $\begin{array}{l}9.33 \quad \mathrm{a} \\
\pm 1.55\end{array}$ & $\begin{array}{l}4.08 \quad \mathrm{a} \\
\pm 1.51\end{array}$ & $\begin{array}{l}4.17 \quad \mathrm{a} \\
\pm 0.83\end{array}$ & $\begin{array}{l}4.63 \\
{ }^{a} \pm 0.85\end{array}$ & $\begin{array}{l}5.25^{\mathrm{a}} \\
\pm 2.22\end{array}$ \\
\hline $\begin{array}{l}\text { Acidity } \\
\left(\mathrm{mgCaCO}_{3} / \mathrm{L}\right)\end{array}$ & $\begin{array}{l}7.83 \quad \mathrm{~b} \\
\pm 2.47\end{array}$ & $\begin{array}{l}6.10 \\
b_{ \pm 2.01}\end{array}$ & $\begin{array}{l}6.50^{\mathrm{a} \mathrm{b}} \\
\pm 1.89\end{array}$ & $\begin{array}{l}6.50^{a b} \\
\pm 1.19\end{array}$ & $\begin{array}{l}4.00 \quad \mathrm{a} \\
\mathrm{b}_{ \pm 0.27}\end{array}$ & $\begin{array}{l}3.00 \quad \mathrm{a} \\
\pm 0.41\end{array}$ & $\begin{array}{l}2.47 \quad \text { a } \\
\pm 0.31\end{array}$ & $\begin{array}{l}5.33^{\mathrm{ab}} \\
\pm 1.27\end{array}$ & $\begin{array}{l}6.58 \quad \mathrm{a} \\
\mathrm{b}_{ \pm 0.34}\end{array}$ & $\begin{array}{l}5.00 \quad \mathrm{a} \\
\mathrm{b}_{ \pm 1.00}\end{array}$ \\
\hline $\begin{array}{l}\mathrm{HCO}_{3}^{-} \\
\left(\mathrm{mgCaCO}_{3} / \mathrm{L}\right)\end{array}$ & $\begin{array}{l}11.90^{\mathrm{a}} \\
\pm 4.97\end{array}$ & $\begin{array}{l}11.90 \\
\pm 5.14\end{array}$ & $\begin{array}{l}9.40 \quad \text { a } \\
\pm 4.63\end{array}$ & $\begin{array}{l}11.80^{\mathrm{a}} \\
\pm 3.58\end{array}$ & $\begin{array}{l}9.20 \quad \mathrm{a} \\
\pm 4.43\end{array}$ & $\begin{array}{l}11.20^{\mathrm{a}} \\
\pm 1.86\end{array}$ & $\begin{array}{l}4.90 \quad \mathrm{a} \\
\pm 1.81\end{array}$ & $\begin{array}{l}5.00 \quad \mathrm{a} \\
\pm 1.00\end{array}$ & $\begin{array}{l}5.55^{\mathrm{a}} \\
\pm 1.02\end{array}$ & $\begin{array}{l}6.30 \\
\pm 2.66\end{array}$ \\
\hline $\begin{array}{l}\mathrm{NO}_{3}^{-} \\
(\mathrm{mg} / \mathrm{L})\end{array}$ & $\begin{array}{l}0.77^{\text {a b }} \\
\pm 0.16\end{array}$ & $\begin{array}{l}0.77^{\mathrm{a} b} \\
\pm 0.16\end{array}$ & $\begin{array}{l}0.46 \quad \text { a } \\
\pm 0.014\end{array}$ & $\begin{array}{l}0.89^{\mathrm{a} b} \\
\pm 0.24\end{array}$ & $\begin{array}{l}1.08 \quad \mathrm{~b} \\
\pm 0.33\end{array}$ & $\begin{array}{l}1.08 \quad \mathrm{~b} \\
\pm 0.07\end{array}$ & $\begin{array}{l}1.33 \quad \mathrm{~b} \\
\pm 0.12\end{array}$ & $\begin{array}{l}0.86^{\mathrm{ab}} \\
\pm 0.14\end{array}$ & $\begin{array}{l}0.46 \quad \text { a } \\
\pm 0.10\end{array}$ & $\begin{array}{l}0.83^{\text {a b }} \\
\pm 0.24\end{array}$ \\
\hline $\begin{array}{l}\mathrm{SO}_{4}{ }^{2-} \\
(\mathrm{mg} / \mathrm{L})\end{array}$ & $\begin{array}{l}0.10 \quad \mathrm{a} \\
\pm 0.01\end{array}$ & $\begin{array}{l}0.10 \\
\pm 0.01\end{array}$ & $\begin{array}{l}0.19 \\
\pm 0.01\end{array}$ & $\begin{array}{l}0.20 \quad \mathrm{c} \\
\pm 0.01\end{array}$ & $\begin{array}{l}0.19 \\
\pm 0.01\end{array}$ & $\begin{array}{l}0.13 \quad \mathrm{~b} \\
\pm 0.01\end{array}$ & $\begin{array}{l}0.14 \quad \mathrm{~b} \\
\pm 0.01\end{array}$ & $\begin{array}{l}0.18 \quad \mathrm{c} \\
\pm 0.01\end{array}$ & $\begin{array}{l}0.18 \\
\pm 0.01\end{array}$ & $\begin{array}{l}0.18 \quad \mathrm{c} \\
\pm 0.02\end{array}$ \\
\hline & $\begin{array}{l}0.17^{\mathrm{ab}} \\
\pm 0.09\end{array}$ & $\begin{array}{l}0.21 \\
\pm 0.07\end{array}$ & $\begin{array}{l}0.09 \quad \text { a } \\
\pm 0.00\end{array}$ & $\begin{array}{l}0.09 \quad \text { a } \\
\pm 0.00\end{array}$ & $\begin{array}{l}0.09 \quad \mathrm{a} \\
\pm 0.00\end{array}$ & $\begin{array}{l}0.11^{\mathrm{a} \mathrm{b}} \\
\pm 0.01\end{array}$ & $\begin{array}{l}0.11^{\mathrm{a} \mathrm{b}} \\
\pm 0.00\end{array}$ & $\begin{array}{l}0.10^{\mathrm{a} \mathrm{b}} \\
\pm 0.00\end{array}$ & $\begin{array}{l}0.10^{\mathrm{a} b} \\
\pm 0.00\end{array}$ & $\begin{array}{l}0.11^{\mathrm{a} \mathrm{b}} \\
\pm 0.00\end{array}$ \\
\hline $\mathrm{K}^{+}(\mathrm{mg} / \mathrm{L})$ & $\begin{array}{l}0.24^{\mathrm{b} \mathrm{c}} \\
\pm 0.10^{0}\end{array}$ & $\begin{array}{l}0.32 \\
\pm 0.10\end{array}$ & $\begin{array}{l}0.10^{\mathrm{a} \mathrm{b}} \\
\pm 0.01\end{array}$ & $\begin{array}{l}0.10^{\mathrm{ab}} \\
\pm 0.02\end{array}$ & $\begin{array}{l}0.10^{\mathrm{a} \mathrm{b}} \\
\pm 0.02\end{array}$ & $\begin{array}{l}0.11^{\mathrm{a} \mathrm{b}} \\
\pm 0.02\end{array}$ & $\begin{array}{l}0.08^{\mathrm{a} \mathrm{b}} \\
\pm 0.01\end{array}$ & $\begin{array}{l}0.09^{\mathrm{a}} \mathrm{b} \\
\pm 0.01\end{array}$ & $\begin{array}{l}0.08 \\
\pm 0.01\end{array}$ & $\begin{array}{l}0.12^{\mathrm{ab}} \\
\pm 0.03\end{array}$ \\
\hline $\mathrm{Mg}^{2+}(\mathrm{mg} / \mathrm{L})$ & $\begin{array}{l}0.07 \quad \text { a } \\
\pm 0.03\end{array}$ & $\begin{array}{l}0.07 \\
\pm 0.01\end{array}$ & $\begin{array}{l}0.07 \\
\mathrm{a}_{ \pm 0.01}\end{array}$ & $\begin{array}{l}0.07 \quad \mathrm{a} \\
\pm 0.01\end{array}$ & $\begin{array}{l}0.07 \\
\mathrm{a}_{ \pm 0.01}\end{array}$ & $\begin{array}{l}0.09 \\
\mathrm{a}_{ \pm 0.02}\end{array}$ & $\begin{array}{l}0.14 \\
\mathrm{~b}_{ \pm 0.01}\end{array}$ & $\begin{array}{l}0.10 \\
\mathrm{a}_{ \pm 0.02}\end{array}$ & $\begin{array}{l}0.10 \\
{ }^{\mathrm{a}} \pm 0.01\end{array}$ & $\begin{array}{l}0.11 \\
\mathrm{a}_{ \pm 0.00}\end{array}$ \\
\hline $\mathrm{Na}^{+}(\mathrm{mg} / \mathrm{L})$ & $\begin{array}{l}0.42 \quad \mathrm{c} \\
\pm 0.18\end{array}$ & $\begin{array}{l}0.40 \\
c_{ \pm 0.10}\end{array}$ & $\begin{array}{l}0.10 \\
{ }^{a} \pm 0.01\end{array}$ & $\begin{array}{l}0.10 \quad \mathrm{a} \\
\pm 0.01\end{array}$ & $\begin{array}{l}0.10 \quad \text { a } \\
\pm 0.01\end{array}$ & $\begin{array}{l}0.12 \\
\mathrm{a}_{ \pm 0.01}\end{array}$ & $\begin{array}{l}0.12 \\
\mathrm{a}_{ \pm 0.01}\end{array}$ & $\begin{array}{l}0.09 \quad \mathrm{a} \\
\pm 0.00\end{array}$ & $\begin{array}{l}0.06 \\
\mathrm{a}_{ \pm} \pm 0.01\end{array}$ & $\begin{array}{l}0.12 \\
\mathrm{a}_{ \pm 0.01}\end{array}$ \\
\hline
\end{tabular}

Note: Values followed by the same alphabet in the same row are not significantly different at $P<0.05$ level according to new Duncan Multiple Range Test.

In Table 3, all the major ionic concentrations were higher in dry season except for $\mathrm{SO}_{4}{ }^{2-}$ and $\mathrm{NO}_{3}{ }^{-}$which are higher during wet season. This may be due to effect of rainfall volume on ionic concentration as earlier reported by Liu (2006), Shimamura et al. (2006) and cited by Haung (2009) that the overall concentrations of ions in Guangzhou, South China precipitation decrease exponentially with increasing rainfall amount. The effect of thunderstorm in the formation of $\mathrm{SO}_{4}{ }^{2-}, \mathrm{NO}_{3}{ }^{-}$could lead to the increase in their concentrations during wet season (Cobinna 2013).

Table 4 shows the rotated component matrix of the analysis. Four factors were observed to contribute to the composition of rainwater samples in this study during the period of sampling. The percentage contributions of the four components in Table 4 are $29.78 \%, 17.86 \%, 16.83 \%$ and $12.12 \%$ respectively for components one to four. 
Table 4. Principal Component Analysis showing Source Apportionment

\begin{tabular}{|c|c|c|c|c|}
\hline Parameter & Component 1 & Component 2 & Component 3 & Component 4 \\
\hline $\mathrm{pH}$ & 0.652 & 0.231 & 0.363 & 0.302 \\
\hline COND & 0.128 & 0.927 & 0.131 & 0.067 \\
\hline TDS & 0.190 & 0.916 & 0.155 & 0.073 \\
\hline Alkalinity & 0.657 & 0.163 & 0.495 & 0.439 \\
\hline Bicarbonate & 0.657 & 0.162 & 0.495 & 0.439 \\
\hline Acidity & 0.030 & -0.019 & 0.168 & -0.814 \\
\hline Nitrate & 0.055 & -0.009 & -0.216 & 0.712 \\
\hline Sulphate & -0.557 & 0.595 & -0.150 & -0.065 \\
\hline $\mathrm{Ca}^{2+}$ & 0.926 & -0.019 & -0.165 & 0.064 \\
\hline $\mathrm{K}^{+}$ & 0.938 & -0.008 & -0.074 & -0.129 \\
\hline $\mathrm{Mg}^{2+}$ & 0.093 & 0.006 & -0.801 & 0.238 \\
\hline $\mathrm{Na}^{+}$ & 0.903 & -0.087 & -0.057 & -0.058 \\
\hline DO & -0.257 & 0.453 & 0.632 & -0.182 \\
\hline $\mathrm{BOD}_{5}$ & -0.325 & 0.529 & 0.420 & -0.053 \\
\hline Turbidity & 0.285 & 0.165 & 0.716 & -0.200 \\
\hline Eigen value & 4.466 & 2.679 & 2.525 & 1.817 \\
\hline$\%$ Variance & 29.776 & 17.861 & 16.833 & 12.116 \\
\hline $\begin{array}{l}\text { Sources of activities } \\
\text { influencing the } \\
\text { parameters }\end{array}$ & $\begin{array}{l}\text { Agricultural activities } \\
\text { (biomass burning) } \\
\text { and soil dust. }\end{array}$ & $\begin{array}{l}\text { Industrial activities, } \\
\text { fuel combustion / } \\
\text { vehicular emissions. }\end{array}$ & $\begin{array}{l}\text { Wood dust and } \\
\text { particulate matters } \\
\text { from saw mill and } \\
\text { agricultural activities }\end{array}$ & Fertilisers \\
\hline
\end{tabular}

Values in bold indicate correlated value for each component

Component One (29.78\%): Based on observation, the component showed high loads of $\mathrm{pH}$, Alkalinity, $\mathrm{HCO}_{3}{ }^{-}$, $\mathrm{Ca}^{2+}, \mathrm{K}^{+}, \mathrm{Na}^{+}$, and $\mathrm{SO}_{4}{ }^{2-}$. The $\mathrm{HCO}_{3}{ }^{-}, \mathrm{Ca}^{2+}, \mathrm{K}^{+}$and $\mathrm{Na}^{+}$indicative of influence of agricultural activities (such as biomass burning) and soil dust. The positive correlations $(\mathrm{P}>0.5)$ observed within these parameters could be responsible for acidic neutralization, increase in Alkalinity and high $\mathrm{pH}$ in rainwater of Agricultural and Residential area (Igwo-Ezikpe and Awodele 2010). However, $\mathrm{SO}_{4}{ }^{2-}$ shows a negative correlation (-0.557) which suggest a buffering factor for the acidity of the rainwater (Igwo-Ezikpe and Awodele 2010).

Component Two (7.86\%): This showed high loads of conductivity, TDS, Sulphate and BOD. The positive correlations of BOD, Conductivity, TDS indicate the influence of industrial dust (Saw mill, Steel melting) (Muhammad and Mooyoung 2008 and Remirez et al. 2010), Sulphate indicates influence of fuel combustion (Sillapapiromsuk and Chantara 2010) and industrial activities (Remirez et al. 2010).

Component Three (16.83\%): The third component showed that Turbidity, DO and $\mathrm{Mg}^{2+}$ are correlated, the higher load of turbidity indicates the influence of wood dust and particulate matters (Yosef and Asmamaw 2015), however, the negative correlation $(-0.801)$ of $\mathrm{Mg}^{2+}$ shows that the dust is not from soil since $\mathrm{Mg}^{2+}$ is one of the dominant cation in most soil (Remirez et al. 2010 and Oden 1976).

Component Four: The fourth component showed high load of positive correlation for Nitrate, and negative correlation for acidity. This indicates that the source of Nitrate is from fertilizer used in agrarian area as supported by Ranjit et al. (1998).

\section{Conclusion}

In the study of spatial variation of rainwater carried out in Ile -Ife and its environ, Osun state of Nigeria from October 2012 to September 2013, the results showed that local land use activities had influence on all the chemical parameters of rainwater in the study area but significantly on $\mathrm{pH}$, Alkalinity, Acidity, Bicarbonate, acid neutralising ions $\left(\mathrm{Ca}^{2+}, \mathrm{Na}^{2+}, \mathrm{K}^{+}\right.$and $\left.\mathrm{mg}^{2+}\right)$. This account for the variation in $\mathrm{pH}$ compared to the $\mathrm{pH}$ of normal 
rainwater with a threshold of 5.6. Temporal variation showed that all the chemical parameters had higher concentration during dry season (October to march) than wet season. except nitrate and sulphate ions, The study also showed that the major sources influencing the chemical parameters in rainwater of the study areas include remobilized dust from industrial activities (Scrap Metal recycling plant and Sawmill Industry), vehicular activities, agricultural activities (burning and fertilizer application) and soil re-suspension.

\section{Acknowledgement}

Special appreciation to Professor I.F Adeniyi, Mr A.I. Aduwo, Mr E.C. Ikpe (Hydrobiological Laboratory); Mr Makinde (Center for Energy and Research Development); Mr Akinola (Obafemi Awolowo University Central Science Lab); Prof. Jegede, Mr Bashiru (Dept. of Physics, Obafemi Awolowo University) for their technical supports on this research work.

\section{References}

Adamu, S. O. (2000). Population Census in Nigeria, SAAL Publication Ltd, Ibadan. Nigeria. pp. 88-89.

Alebic-Juretic, A., \& Sojat, V. (1998). Chemical composition of rainwater collected at two sampling sites in the city of Rijeka. Arhiv Za Higijenu Rada I Toksikologiju, 49(3), 245-250.

Anderson, J. R., Hardy, E. E., \& Roach, J. T. (1976). A land-use classification system for use with remote-sensor data: United State Geological. Survey Core. 671, pp 16.

Arlo, W. G., \& Donald, W. F. (2012). Occurrence of Sulfate and Nitrate in rainfall. Journal of Geophysical Research, 69, 4203-4210.

Atobatele, O. A. (2008). Seasonal variation in the physicochemistry of a small tropical reservoir (Aiba Reservoir, Iwo, Osun, Nigeria). African Journal of Biotechnology, 7(12), 1962-1972. https://doi.org/10.5897/AJB2008.000-5043

Chughtai, M., Mustafa, S., \& Mumtaz, M. (2014). Study of Physicochemical Parameters of Rainwater: A Case Study of Karachi, Pakistan. American Journal of Analytical Chemistry, 5, 235-242. http://dx.doi.org/10.4236/ajac.2014.54029

Cobbina, S. J., Michael, K., Salifu, L., \& Duwiejua, A. B. (2013). Rainwater Quality Assessment In The Tamale Municipality. International Journal of Scientific and Technology Research, 2(5).

Dorothy, C. (1962). Rainwater as a Chemical Agent of Geological Processes - A review, Geological Survey Water-Supply Paper. U.S Government Printing Office. 1535-G.

Efe, S. I. (2005). Urban effects on precipitation amount, distribution and rainwater quality in Warri metrololis, Ph. D. Thesis Department of Geography and Regional Planning, Delsu-Abraka, pp. 10-103.

Efe, S. I. (2006). Quality of rainwater harvesting for rural communities of Delta State, Nigeria. J. Environmentalist, 26(3), 175-181. https://doi.org/10.1007/s10669-006-7829-6

Efe, S. I. (2010). Spatial variation in acid and some heavy metal composition of rainwater harvesting in the oil producing region of Nigeria. Natural Hazard, 5, 307-319. https://doi.org/10.1007/s11069-010-9529-2

Efe, S. I. (2011). Spatial Variation of Acid Rain and its Ecological Effect in Nigeria. Proceedings of the Environmental Management Conference, Federal University of Agriculture, Abeokuta, Nigeria, 2011.

Galloway, J. N., Likens, G. E., Keene, W. C., \& Miller, J. M. (1982). The composition of Precipitation in Remote areas of the world. Journal of Geophysical Research, 87(11), 8771-8786. https://doi.org/10.1029/JC087iC11p08771

Huang, D. (2009). Chemical composition and seasonal variation of acid deposition in Guangzhou south china. Journal of environmental sciences, 21(5), 654-60. https://doi.org/10.1016/S1001-0742(08)62321-9

Igwo-Ezikpe, M. N., \& Awodele, O. (2010). Investigation of Some Physico-chemical and Microbiological Parameters in Rainwater Collected from Industrial Areas of Lagos State, Nigeria. African Journal of Pharmaceutical Sciences, 1, 26-38.

Jitendra, P. (2012). Chemical characterization of rain water in a seasonally dry tropical region (Varanasi), India. Journal of Environmental Biology, 33, 629-634.

Kondal, R. Y., Priyanka, M., Raghu, V., Saireddy, N. R., Sai, K., \& Mamatha, M. (2011). Analytical study and microorganisms present in rain water of different areas. International Journal of Environmental Sciences, 2(1). 
Liu, H., James, H. C., Robert, B. P., Peter, N., Steve, E., Gao, C., ... Xeuxi, T. (2006). Radiative effect of cloud on tropospheric chemistry in a global three-dimensional chemical transport model. Journal of geophysical research, 111, D20303. https://doi.org/10.1029/2005jd006403

Muhammad, T. A., \& Mooyoung, H. (2008). Probable sources of microbial contamination of stored rainwater and its remediation. Seoul National University, Seoul, Korea.

Narayana, S. (1991). Chemical Composition and Temporal Variation of Bulk Precipitation at Visakhapatnam, India Department of Geophysics, Andhra University, Visakhapatnam530 003, India. Hydrological Interactions between Atmosphere, Soil and Vegetation Proceedings of the Vienna Symposium, August 1991. IAHS Publ.No.204.

Oden, S. (1976). The acidification of air and precipitation and its consequences in the natural environment. Ecology Committee Bulletin, No. 1, Swedish National Science Research Council, Stockholm.

Ogunfowokan, A. O., Asubiojo, A. A., Adeniyi, A. A., \& Oluyemi, E. A. (2004). Trace Lead, Zinc, Copper Levels in Barbula lambarenensis as a monitor of Local Atmospheric Pollution in Ile-Ife, Nigeria. Journals of Applied Sciences, 4(30), 380-383.

Prospero, J. M. (1979). Mineral and sea salt aerosol concentrations in various ocean regions. J. Geophys. Res., 84(C2), 725-731. https://doi.org/10.1029/JC084iC02p00725

Ranjit, K., Abha, R. K, Mharaj, K., \& Scrivastava, S. S. (1998). Direct measurement of atmospheric dry deposition to natural surfaces in a semiarid region of North central, India. Journal of Geophysical Research, 108(D20), 4625.

Remirez, E. L., Guardiola, R. M., Vasquez, Y. G., Balderas R. I., Alverez, B. S., Jimenez, M. C., \& Kharl, J. T. (2010). Chemical Composition of Rainwater in Northeastern Mexico. Atmosfera, 23(3), 213-224.

Salami, O. O., Awotoye, O. O., \& Owoade, O. K. (2014). Markers of Environmental Health: Nickel and Chromium Levels in Soil and Vegetation around a Steel Recycling Facility in Southwest Nigeria. British Journal of Applied Science \& Technology, 4(7), 1060-1070. https://doi.org/10.9734/BJAST/2014/5733

Shimamura, T., Wada, T., Iwashita, M., Takaku, Y., \& Ohashi, H. (2006). Scavenging properties of major and trace species in rainfall collected in urban and suburban Tokyo. Atmospheric Environment Journal, 40, 4220-4227. https://doi.org/10.1016/j.atmosenv.2006.03.010

Shivashankara, \& Nagendra. (2012). Wet and Bulk Precipitation Chemistry at Urban Area in Karnataka, India. 2nd International Conference on Biotechnology and Environment Management IPCBEE vol.42: 22.

Sillapapiromsuk, S., \& Chantara, S. (2010). Chemical Composition and Seasonal Variation of Acid Deposition in Chiang Mai, Thailand. Environmental Engineering Research June, 15(2), 93-98. https://doi.org/10.4491/eer.2010.15.2.093

WHO, World Health Organization. (2011). Guidelines for Drinking-water Quality (4th ed.). Geneva 27, Switzerland. Retrieved from www.who.int/whr/2011/en/

Yosef, B. A., \& Asmamaw, D. K. (2015). Rainwater harvesting; An option for dry land agriculture in arid and semi-Arid Ethiopia. International Journal of Water Resources and Environmental Engineering, 7(2), 17-28. https://doi.org/10.5897/IJWREE2014.0539

\section{Copyrights}

Copyright for this article is retained by the author(s), with first publication rights granted to the journal.

This is an open-access article distributed under the terms and conditions of the Creative Commons Attribution license (http://creativecommons.org/licenses/by/4.0/). 